\title{
The Value of Black Monukka, Perlette, Ruby Seedless and Sultanina as parents for breeding Raisin Grapes
}

\author{
E. P. EVANS AND C. J. SMIT \\ Viticultural and Oenological Research Institute, Private Bag X5026, 7600 Stellenbosch, Republic of South Africa.
}

Submitted for publication: August 1985

Accepted for publication: October 1985

Keywords: Breeding, cultivars, seedless, drying

\begin{abstract}
The seedless grape cultivars Black Monukka, Perlette, Ruby Seedless and Sultanina were used as pollen parents and hybridized with two muscat flavoured and four neutral flavoured cultivars and selections in an effort to breed seedless table grapes. The progeny of some of these crosses were also evaluated for raisin quality during the $1983 / 84$ season. Ten seedless selections and 21 selections possessing trace seeds (1-2 mm) obtained a quality rating comparable to that of Merbein Seedless, Fiesta, Perlette and Sultanina raisins. Perlette produced four times as many seedlings with satisfactory raisin quality as all the other crosses combined. The cross CG $1272 \times$ Sultanina produced five promising white currant types. Selection CG 1272 appears to be a valuable parent for breeding improved currant types.
\end{abstract}

The production of raisins is of considerable importance to many farmers in irrigation areas of the Republic of South Africa. The mean annual production for the 1979 to 1983 seasons was $26457 \mathrm{t}$ (Anon., 1983), whilst the production for 1984 was $32006 \mathrm{t}$ (D. C. Viljoen - personal communication, 1985).

Mainly Sultanina and Muscat of Alexandria are used for the production of raisins because of their excellent drying qualities. Ninety two per cent of all raisins produced in South Africa are derived from the former cultivar (Anon., 1983).

The main production areas are located in the Western and North-western regions of the Cape Province. Although these areas are relatively hot and dry, summer rains occasionally occur during the ripening and harvesting period. These rains cause the berries of Sultanina to split and rot resulting in considerable economic losses to farmers. This cultivar is very prone to growth arrestment disease (Saayman, 1983). There is therefore a need to develop a Sultanina type of grape which is less prone to growth arrestment disease, is more split-resistant and possesses the drying and other desirable qualities of Sultanina.

An important objective of the table grape breeding programme is to breed muscat flavoured, seedless table grapes. This material was also evaluated for its drying potential.

\section{MATERIAL AND METHODS}

Selection of seedlings and drying of grapes: The progeny of certain crosses between the seedless cultivars Black Monukka, Perlette, Ruby Seedless and Sultanina and the six female parents namely the muscat flavoured cultivars Muscat of Alexandria and Erlihane [(Muscat of Alexandria $\times$ Queen of the Vineyard) $\times$ Muscat of Alexandria] and the neutral flavoured cultivars Phraoula and selections B13-16, CG 1272 and K7/16-1 were evaluated for their drying potential.

The grapes of the seedlings were screened in the vineyard and only those with a reasonably firm texture were selected for drying. Seedlings which produced seeded, coloured grapes were discarded at this stage as there is no demand for this type of raisin. Three or four clusters per seedling weighing $1,5 \mathrm{~kg}$ to $2,5 \mathrm{~kg}$ were harvested when the total soluble solids content of the berries had reached $20^{\circ}$ Brix. The clusters were dipped in the standard cold lye dip consisting of a $2 \%$ Sultanol and $2,5 \%$ potassium bi-carbonate solution. Thereafter they were placed on plastic trays and dried in a plastic tunnel. The temperature in the tunnel varied between $35^{\circ} \mathrm{C}$ and $44^{\circ} \mathrm{C}$ during the drying period. Thermostatically controlled fans set at $45^{\circ} \mathrm{C}$ were used to extract excessive heat and to prevent caramelisation and puffiness of the raisins. Under these conditions the drying process was completed within 7 to 12 days. The clusters were turned by hand once or twice during this period to ensure even drying of the berries. The dried samples were then stored at $-10^{\circ} \mathrm{C}$ to $-15^{\circ} \mathrm{C}$ until winter (May) when they were removed, destalked and the raisin quality evaluated.

Evaluation of raisins: The quality of the raisin samples was evaluated by two separate panels. A preliminary evaluation to eliminate samples which were of substandard quality was conducted by six panelists of the Viticultural and Oenological Research Institute at Stellenbosch. The samples were classified according to raisin size, colour and seededness. Samples which passed this test were finally evaluated by a consumer panel consisting of six members selected from the trade by the Dried Fruit Board. To obtain a percentage score the general impression of the raisins was rated from 1 to 5, taking appearance, texture and palatability into account. The cultivars Sultanina, Perlette, Merbein Seedless and Fiesta were included as standards for comparison.

Screening raisins for seed traces: Berry set in seedless cultivars can either be parthenocarpic or stenospermocarpic (Winkler et al., 1974). Black Corinth is a typical example of parthenocarpic berry set. In this case pollination stimulus alone is sufficient for berry set; ovule development ceases after bloom and no seeds or seed traces are formed.

The berry development of Sultanina, Perlette and Black Monukka on the other hand is stenospermocarpic. Here the ovules are fertilized but abort soon afterwards. The 
TABLE 1

Number of selections producing quality raisins obtained from crosses of seeded $X$ seedless cultivars: $1983 / 84$ season.

\begin{tabular}{|c|c|c|c|c|c|c|c|c|c|c|c|c|c|}
\hline Type of Raisins & Seed ${ }^{\prime}$ & Colour & $\begin{array}{c}\text { Muscat } \\
\text { of } \\
\text { Alexandria }\end{array}$ & Erlihane & B13-6 & Phraoula & $\begin{array}{c}\text { Muscat } \\
\text { of } \\
\text { Alexandria }\end{array}$ & $\underset{\times}{\text { Sultanir }}$ & $\underset{x}{\text { Sultanina }}$ & K7/16-1 & $\begin{array}{c}\text { Ruby } \\
\text { Seedless } \\
\times \\
\text { Muscat } \\
\text { of } \\
\text { Alexandria }\end{array}$ & \multicolumn{2}{|c|}{$\left.\right|_{B 13-6} ^{\text {Bhack Monukka }}$} \\
\hline $\begin{array}{l}\text { 1. Currant } \\
\text { 2. Sultana } \\
\text { 3. Intermediate }{ }^{2} \\
\text { 4. Muscat of Alexandria }\end{array}$ & $\begin{array}{l}\text { none } \\
\text { none } \\
\text { none } \\
\text { trace } \\
\text { trace } \\
\text { none } \\
\text { trace } \\
\text { seeded }\end{array}$ & $\begin{array}{l}\text { white } \\
\text { white } \\
\text { black } \\
\text { white } \\
\text { black } \\
\text { white } \\
\text { white } \\
\text { white }\end{array}$ & $\begin{array}{l}1 \\
2\end{array}$ & $\begin{array}{r}2 \\
4 \\
10 \\
1 \\
14\end{array}$ & 1 & $\begin{array}{l}1 \\
3 \\
1\end{array}$ & 1 & $\begin{array}{l}1 \\
1\end{array}$ & 5 & 1 & $\begin{array}{l}2 \\
1 \\
2\end{array}$ & 1 & \\
\hline \multicolumn{2}{|c|}{$\begin{array}{l}\text { Total no. promising selections } \\
\text { Population size } \\
\% \text { Promising/female parent }\end{array}$} & & $\begin{array}{r}5 \\
103 \\
4,9\end{array}$ & $\begin{array}{c}31 \\
712 \\
4,4\end{array}$ & $\begin{array}{r}4 \\
126 \\
3,2\end{array}$ & $\begin{array}{r}5 \\
75 \\
6,7\end{array}$ & $\begin{array}{r}2 \\
457 \\
0,4\end{array}$ & $\begin{array}{r}3 \\
185 \\
1,6\end{array}$ & $\begin{array}{r}5 \\
170 \\
2,9\end{array}$ & $\begin{array}{r}1 \\
190 \\
0,5\end{array}$ & $\begin{array}{r}6 \\
508 \\
1,2\end{array}$ & $\begin{array}{r}1 \\
64 \\
1,6\end{array}$ & $\begin{array}{r}0 \\
21 \\
0,0\end{array}$ \\
\hline
\end{tabular}

Inone $=$ traces $<1 \mathrm{~mm}$

trace $=$ traces $1-2 \mathrm{~mm}$.

${ }^{2}$ Sultanina and Muscat of Alexandria.

berries of these cultivars, however, contain rudimentary seeds usually not noticable in most Sultanina and Perlette grapes but in the case of Black Monukka they are detectable (Christensen, Ramming \& Andris, 1983), the seed traces of this cultivar being in the 1-2 mm category. When breeding seedless table and raisin grapes, the aim is complete seedlessness.

To differentiate between seeded and seedless raisins, the raisins were rolled between thumb and forefinger. Seeded raisins were easily detected by this method. In the case of seedless raisins which contain seed traces similar in size to those of Fiesta or Sultanina, an overhead projector was used to screen the samplese Fifteen raisins per sample were pressed flat between the fingers and placed on the glass platform of the projector. By passing light through the raisins, it was possible to classify the samples according to the size of the seed traces in $1 \mathrm{~mm}$ (light coloured traces) and 1-2 mm (dark coloured traces) groups.

\section{RESULTS AND DISCUSSION}

Selection pressure: Twenty one per cent of the population i.e. 548 seedlings were considered suitable for drying. After the completion of the initial evaluation only 19 per cent, i.e. 104 samples, were retained for a more critical evaluation by the consumer panel. Sub-standard samples were discarded because of:

- lack of pulp texture, coarsely creased and skinny appearance;

- unattractive, dull or too dark colour or stickiness;

- excessive seededness or very large seeds;

- a mixture of large seeded and small seedless raisins;

- a mixture of large and small seedless berries.

On completion of the second evaluation by the consumer panel only samples which obtained an overall rating above 50 per cent for appearance, texture and palatability were retained. This reduced the number to 63 selections i.e. 2,4 per cent of the original population.
The number of selections derived from the various crosses and the type of raisins obtained are presented in Table 1.

Breeding value of seedless parents: Perlette exhibited the strongest potency to transmit acceptable drying qualities to its progeny. All crosses in which Perlette was used as pollen parent produced a higher percentage of seedlings with desirable drying quality than any of the other seedless pollen parents. On an average, Perlette produced three to four times as many promising selections as any of the other combinations. In combination with Muscat of Alexandria, Perlette $(4,9)$ produced four times as many seedlings with good drying potential as Ruby Seedless $(1,2)$ did. In comparison with Sultanina, Perlette's potency $(4,9)$ was more than twelve times greater when crossed with Muscat of Alexandria $(0,4)$.

When comparing Perlette and Sultanina as male parents in combination with Erlihane it is again evident that Perlette $(4,4)$ produced approximately three times more seedlings with satisfactory drying quality than Sultanina $(1,6)$.

The results of the cross CG $1272 \times$ Sultanina should be of significance in a currant breeding programme in that many of the seedlings of CG 1272 (ex Rama Caida, Argentine) produced currant-sized berries. All the selections with drying potential originating from this combination were white currant types (Table 1).

Quality rating of selection - Sultanina type raisins: Selections which produced seedless raisins (Group I) or raisins with 1-2 mm seed traces (Group II) with a quality rating comparable to that of Sultanina are listed in Table 2. Only selections which obtained a rating of 50 per cent or higher were provisionally retained.

The three Sultanina clones H4, H5 and 14/2 were included as standards. The locally selected clone $14 / 2$ which tends to produce uneven sized berries was inferior in quality to the two Australian clones H4 and H5. Recent indications are that $\mathrm{H} 5$ is slightly superior to $\mathrm{H} 4$ as a table grape and is preferred in new plantings in South Africa. 
TABLE 2

Quality rating of selections which produce Sultana type raisin: 1983/84

\begin{tabular}{|c|c|c|c|c|c|}
\hline \multicolumn{3}{|c|}{$\begin{array}{c}\text { GROUP I } \\
\text { Seedless raisins }\end{array}$} & \multicolumn{3}{|c|}{$\begin{array}{c}\text { GROUP II } \\
\text { Raisins with } 1-2 \mathrm{~mm} \text { seed traces }\end{array}$} \\
\hline $\begin{array}{l}\text { Selection/ } \\
\text { cultivar }\end{array}$ & $\begin{array}{l}\text { Score } \\
(\%)\end{array}$ & $\begin{array}{l}\text { Parentage } \\
\text { (a) }\end{array}$ & $\begin{array}{l}\text { Selection/ } \\
\text { cultivar }\end{array}$ & $\begin{array}{c}\text { Score } \\
(\%)\end{array}$ & $\begin{array}{l}\text { Parentage } \\
\text { (a) }\end{array}$ \\
\hline $\begin{array}{l}\text { Merbein Seedless } \\
12-29-103 \\
\text { G1-3-40 } \\
\text { Fiesta } \\
12-26-53 \\
12-17-53 \\
\text { Sultanina }\left(\mathrm{H}_{5}\right) \\
\text { Sultanina }\left(\mathrm{H}_{4}\right) \\
12-23-44 \\
\text { G1-12-3 } \\
12-17-1 \\
\text { G1-13-12-5 (b) } \\
\text { Sultanina }(14 / 2) \\
\text { Perlette } \\
12-32-95 \\
12-38-12\end{array}$ & $\begin{array}{l}70 \\
68 \\
66 \\
65 \\
62 \\
62 \\
62 \\
60 \\
58 \\
57 \\
56 \\
56 \\
55 \\
54 \\
52 \\
50\end{array}$ & $\begin{array}{l}1 \\
1 \\
2 \\
4\end{array}$ & $\begin{array}{l}12-16-66 \\
12-16-65 \\
\text { G1-14-12 } \\
12-40-60 \\
12-28-87 \\
12-29-56 \\
12-29-3 \\
12-27-64 \\
12-26-74 \\
12-29-102 \\
\text { G1-13-5-2 (b) } \\
12-31-31 \\
12-37-81 \\
12-17-55 \\
12-41-98 \quad \text { (b) } \\
\text { G1-14-4-5 (b) } \\
\text { G3-13-45 (b) } \\
12-29-18 \\
12-37-60 \\
12-28-54 \\
12-30-88\end{array}$ & $\begin{array}{l}67 \\
66 \\
65 \\
62 \\
62 \\
61 \\
59 \\
57 \\
58 \\
58 \\
58 \\
57 \\
56 \\
56 \\
56 \\
54 \\
50 \\
50 \\
50 \\
50 \\
50\end{array}$ & $\begin{array}{l}3 \\
3 \\
1 \\
8 \\
1 \\
1 \\
1 \\
1 \\
5 \\
1 \\
4 \\
1 \\
7 \\
2 \\
7 \\
4 \\
4 \\
1 \\
7 \\
1 \\
1\end{array}$ \\
\hline
\end{tabular}

(a) $=1$. Erlihane $\times$ Perlette

2. Muscat of Alexandria $\times$ Perlette

3. B13-6 $\times$ Perlette

4. Phraoula $\times$ Perlette

5. Erlihane $\times$ Sultanina

6. Muscat of Alexandria $\times$ Sultanina

7. Muscat of Alexandria $\times$ Ruby Seedless

8. Muscat of Alexandria $\times$ Black Monukka

(b) = black colour

There is, however, no significant quality difference between the raisins of clone $\mathrm{H} 4$ and $\mathrm{H} 5$.

Two cultivars, Merbein Seedless and Fiesta and the selections 12-29-103, G 1-3-40, 12-26-53 and 12-17-53 gained a similar or slightly higher rating than clone $\mathrm{H} 5$. In Group II selections 12-16-66, 12-16-65, G 1-14-12, 1240-60 and 12-28-87 gained a similar or higher rating than clone $\mathrm{H} 5$.
Since environmental conditions may influence seed trace development, these selections will now be evaluated in various localities within the raisin production areas of the Western and North Western Cape Province. They will also be evaluated for their viticultural qualities, such as split resistance, fertility and yield, ability to dry on the vine and raisin quality.

\section{CONCLUSION}

The seedless cultivars Perlette, Sultanina, Ruby Seedless and Black Monukka used as pollen parents in a breeding programme, differed in their potency to transmit their raisin quality to their progeny. Perlette exhibited a marked potency to produce a larger number of seedlings possessing good raisin quality than any other pollen parent. Perlette should therefore be a most valuable pollen parent in a raisin grape breeding programme.

The majority of the seedling progeny of the Argentinian selection CG 1272 produced currant-sized berries. This selections should be a useful parent in a currant breeding programme.

\section{LITERATURE CITED}

ANON., 1983. Forty fifth annual report: Dried Fruit Board, P.O. Box 522, Wellington, Republic of South Africa, 30.

CHRISTENSEN, P. L., RAMMING, D. \& ANDRIS, H., 1983. Seed trace content of Fiesta grapes. Am. J. Enol. Vitic. 34(4), 257-259.

SAAYMAN, D., 1983. Investigations into the causes and control of the growth arrestment phenomenon of Sultana. 1. Symptoms and survey results. S. Afr. J. Enol. Vitic. 4(1), 21-26.

WINKLER, A. J., COOK, J. A., KLIEWER, M. W. \& LIDER, L. A., 1974. General Viticulture. Univ.Calif. Press, Berkeley. 